\title{
CREATION AND REGULATION OF ORGANIZATIONAL STRUCTURES OF ENTERPRISES
}

\section{СТВОРЕННЯ І РЕГУЛЮВАННЯ ОРГСТРУКТУР ПІДПРИЕМСТВ}

\author{
Vilgutska Roksolana ${ }^{1}$ \\ Kazymyra Iryna ${ }^{2}$
}

DOI: https://doi.org/10.30525/978-9934-571-78-7_2

\begin{abstract}
Each and all domestic and foreign enterprises have experience in the formation and use of organizational structures as a component of management systems, although the research conducted indicates that quite a lot of existing organizational structures have irrational structure, staff overage, violations of feedbacks from subordinates to executives, are characterized by duplication of functions of structural subdivisions and individual officials, etc. Critical analysis of empirical data and materials of scientists allows stating that the problem is determined by underdevelopment of scientifically substantiated methodical and applied tools as regards to the formation and use of organizational structures by enterprises. Most of scientific papers related to the formation and use of organizational structures pay attention to types of organizational structures, substantiation of the choice of the type of organizational structures for particular enterprises, problems of their reorganization in mergers and acquisitions, information and communication support of organizational structures, evaluation of the efficiency of using organizational structures and so on. The existing theoretical-methodological and applied developments in relation to the formation and use of organizational structures are characterized by fragmentariness, not systemacity; in particular, methodological provisions for the formation of organizational structures and their regulation remained out of the attention of scientists. This actualizes development of theoretical
\end{abstract}

\footnotetext{
${ }^{1}$ Candidate of Economic Sciences,

Assistant Lecturer at Department of Management and International Entrepreneurship,

Lviv Polytechnic National University, Ukraine

${ }^{2}$ Candidate of Engineering Sciences, Associate Professor,

Senior Lecturer at Department of Ecological Safety and Nature Protection Activity,

Lviv Polytechnic National University, Ukraine

(C) Vilgutska Roksolana, Kazymyra Iryna
} 
and methodological-applied provisions on the formation and regulation of organizational structures of enterprises.

\section{1. Ветуп}

Матричні оргструктури $є$ прийнятними для виникнення синергічних ефектів. Вони виникають через те, що у матричних структурах передбачаються певні типові компоненти, які за будовою, а також лінійно-функціональними зв'язками з іншими компонентами дублюються. Тобто, один раз розробивши алгоритм побудови певної компоненти оргструктури у подальшому його можна використовувати для дублювання таких інших аналогічних компонентів. Крім того, матричні оргструктури можуть будуватись не лише за видами реалізовуваних проектів, але й передбачати географічне чи продуктове диференціювання, тобто вони є сукупністю фракталів. Використання фрактальності у якості властивості матричних оргструктур для збільшення ї масштабу сприяє зростанню резервів часу на формування оргструктури.

На необхідність реорганізації, здебільшого, вказує неспроможність оргструктури забезпечити необхідну субординацію між посадовими особами і структурними підрозділами, а також нездатність структурних підрозділів виконувати покладені на них функції, що унеможливлює реалізацію поставлених перед ними цілей. За результатами проведених досліджень нами побудовано матрицю трактування значень коефіцієнтів, які характеризують оргструктуру за критерієм реалізації встановлених цілей. Значення коефіцієнтів у матриці можна використовувати для аргументації необхідності реорганізації оргструктури.

\section{2. Матрично-мережевий підхід до формування оргструктур підприсмств}

Крупні підприємства здебільшого використовують матричні оргструктури. Вони належать до структур адаптивного типу, які за характером $\epsilon$ комбінованими. Матричні оргструктури $є$ двовимірними, оскільки можуть будуватись не лише за типом зв'язків між структурними підрозділами підприємства (лінійні і функціональні), але й за видами реалізовуваних проектів, за регіональною ознакою, видом продукції, що виробляє підприємство, тощо. В умовах застосування матричних оргструктур можливим $€$ виникнення синергічних ефектів. 


\section{Chapter «Economic sciences»}

Критичний аналіз видів подій, сукупність яких репрезентує процес формування матричних оргструктур підприємств, дозволяє стверджувати, що синергічні ефекти від їх побудови найбільш очевидні тоді, коли матриці формуються у поєднанні із методом побудови мережевих графів. В матричних структурах передбачаються певні типові компоненти, які за будовою і зв'язками з іншими компонентами дублюються. Так, якщо побудова матричної оргструктури здійснюється за видами проектів, то загальне керівництво різними аспектами усіх виконуваних проектів відбуватиметься за відповідними лінійними вертикалями. Тобто, один раз розробивши алгоритм, в подальшому його можна використовувати для дублювання таких інших аналогічних компонентів, що сприятиме виникненню ефекту синергії. Матрично-мережевий підхід до формування оргструктури вимагає ідентифікування переліку подій, які дозволять сконструювати мережевий граф матричної оргструктури (табл. 1).

Емпіричні та експертні дослідження, дозволили встановити тривалість виконання робіт у мережевому графі формування матричної оргструктури. У табл. 2 наведено узагальнені результати отриманої експертної інформації.

За результатами проведених досліджень виявилось, що найбільші витрати часу пов'язані із формуванням посадових інструкцій управлінських працівників, а також положень про структурні підрозділи підприємства. Це пов'язано із працемісткістю підготовки цих документів, а також їх кількістю. Аналізування отриманих даних показало, що в середньому на момент створення оргструктури кожне промислове підприємство формує по десять структурних підрозділів, у кожному з яких, у середньому, по п'ять осіб. Як наслідок, левова частка витрат часу припадає саме на виконання цих видів робіт.

На рис. 1 представлено побудованих мережевий граф формування матричної оргструктури.

Початкова подія «1»є вершиною нульового рангу. Її виконанню не передують жодні роботи, тому ця вершина не може мати резервів часу. Подія «16» $є$ вершиною кінцевого п'ятнадцятого рангу. Таким чином, усі вершини пронумеровані у довільному порядку на основі неперервного числа натурального ряду. Резерви часу цього графа можуть лежати в межах від першого до п'ятнадцятого рангу відповідних подій. Враховуючи змістове наповнення кожної події відповідного 


\section{Перелік подій у мережевому графі формування матричної оргструктури}

\begin{tabular}{|c|c|}
\hline № & Види робіт мережевого графа \\
\hline 1 & Встановлення видів управлінської діяльності \\
\hline 2 & Формування загальної моделі управління підприємством \\
\hline 3 & $\begin{array}{l}\text { Побудова інституційного рівня управління шляхом графічного } \\
\text { відображення управлінських посадових осіб на цьому рівні }\end{array}$ \\
\hline 4 & $\begin{array}{l}\text { Формування посадових інструкцій для управлінських посадових осіб } \\
\text { на інституційному рівні управління }\end{array}$ \\
\hline 5 & $\begin{array}{l}\text { Закріплення за посадовими особами інституційного рівня управління } \\
\text { обов’язків, функцій, відповідальності }\end{array}$ \\
\hline 6 & $\begin{array}{l}\text { Побудова середнього рівня управління шляхом виділення структурних } \\
\text { підрозділів підприємства }\end{array}$ \\
\hline 7 & $\begin{array}{l}\text { Встановлення лінійного підпорядкування структурних підрозділів цього } \\
\text { рівня керівникам інституційного рівня }\end{array}$ \\
\hline 8 & $\begin{array}{l}\text { Установлення функціональних зв’язків між структурними підрозділами } \\
\text { цього рівня }\end{array}$ \\
\hline 9 & $\begin{array}{l}\text { Формування положень про структурні підрозділи середнього рівня } \\
\text { управління }\end{array}$ \\
\hline 10 & $\begin{array}{l}\text { Формування посадових інструкцій працівників структурних підрозділів } \\
\text { середнього рівня управління }\end{array}$ \\
\hline 11 & $\begin{array}{l}\text { Побудова низового (технічного) рівня управління шляхом виділення } \\
\text { структурних підрозділів на цьому рівні }\end{array}$ \\
\hline 12 & $\begin{array}{l}\text { Встановлення лінійного підпорядкування структурних підрозділів цього } \\
\text { рівня керівникам середнього рівня управління }\end{array}$ \\
\hline 13 & $\begin{array}{l}\text { Встановлення функціонального підпорядкування між структурними } \\
\text { підрозділами та посадовими особами даного рівня на посадовими особами } \\
\text { інших рівнів управління }\end{array}$ \\
\hline 14 & $\begin{array}{l}\text { Формування положень про структурні підрозділи низового рівня } \\
\text { управління підприємством }\end{array}$ \\
\hline 15 & $\begin{array}{l}\text { Формування посадових інструкцій працівників низового рівня управління } \\
\text { підприємством }\end{array}$ \\
\hline 16 & Затвердження проекту оргструктури \\
\hline
\end{tabular}


Таблиця 2

Тривалість формування матричної оргструктури

\begin{tabular}{|c|c|c|c|}
\hline $\begin{array}{c}\text { Дуги, які } \\
\text { з'сднують події }\end{array}$ & $\begin{array}{c}\text { Тривалість } \\
\text { виконання робіт }\end{array}$ & $\begin{array}{c}\text { Дуги, які } \\
\text { 3'сднують події }\end{array}$ & $\begin{array}{c}\text { Тривалість } \\
\text { виконання робіт }\end{array}$ \\
\hline $1-2$ & 16 & $9-10$ & 400 \\
\hline $2-3$ & 8 & $10-11$ & 8 \\
\hline $3-4$ & 8 & $11-12$ & 8 \\
\hline $4-5$ & 40 & $11-14$ & 88 \\
\hline $5-6$ & 8 & $12-13$ & 8 \\
\hline $6-7$ & 8 & $13-14$ & 80 \\
\hline $6-9$ & 88 & $14-15$ & 400 \\
\hline $7-8$ & 8 & $15-16$ & 8 \\
\hline $8-9$ & 80 & & \\
\hline
\end{tabular}

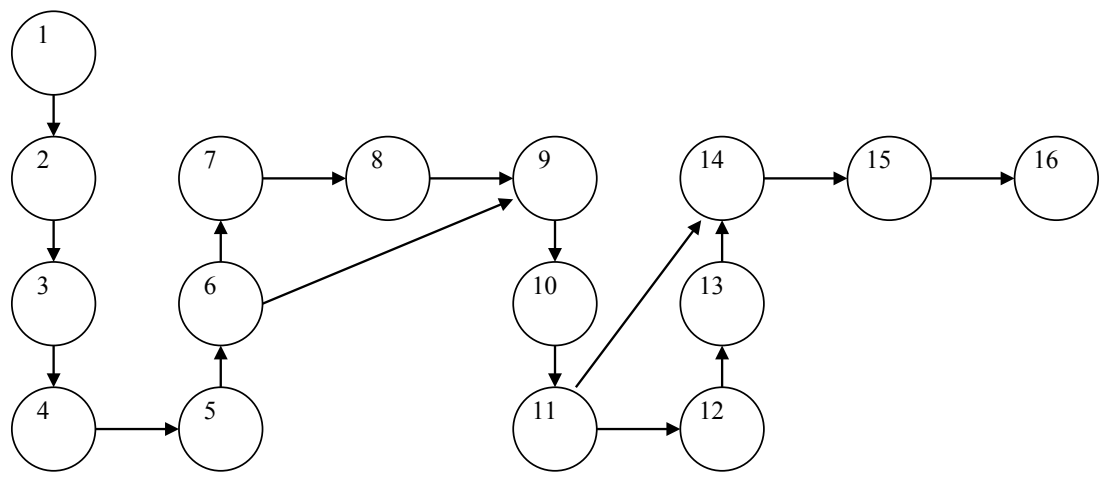

\section{Рис. 1. Мережевий граф формування матричної оргструктури}

рангу (див. табл. 2), а також ідентифіковані витрати часу на реалізацію цих подій (див. табл. 3), нами виявлено критичний шлях мережевого графа формування матричної оргструктури (рис. 2).

Критичним називають шлях із найбільшим терміном серед усіх завершених шляхів. Хоча у мережевому графі, що наведений на рис. 2, лише один критичний шлях, можливі випадки, коли критичних шляхів $\epsilon$ кілька. Під час аналізу мережевого графа, окрім критичного, необхідно визначити і максимальний шлях. На рис. 3 наведено максимальний шлях мережевого графа формування матричної оргструктури. 


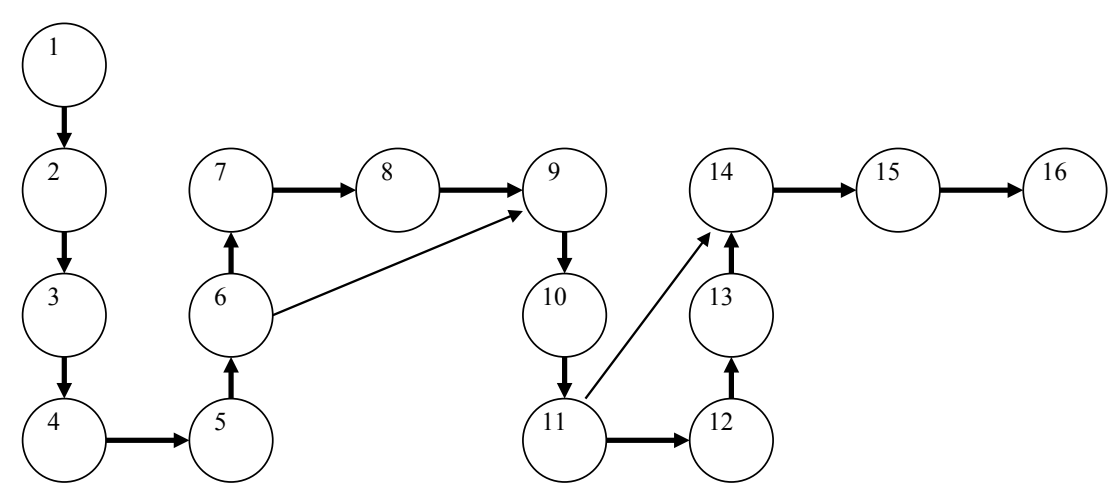

Рис. 2. Критичний шлях мережевого графа формування матричної оргструктури

Примітка: жирними стрілками показано критичний шлях

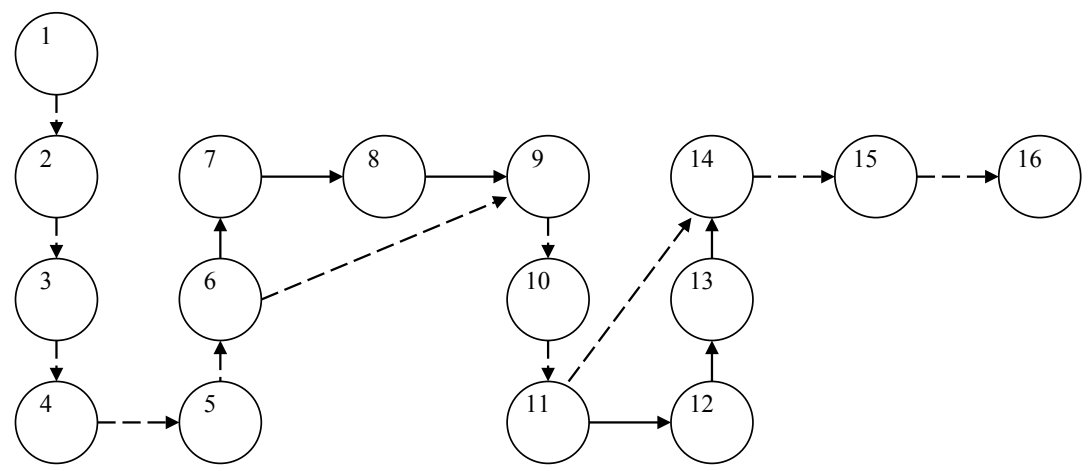

Рис. 3. Критичний шлях мережевого графа формування матричної оргструктури

Примітка: пунктирною лінією позначено максимальний шлях

Отже, є чотири часових варіанти побудови матричної оргструктури. Кожен із варіантів репрезентує повний шлях побудованого мережевого графа, оскільки кожен із них може досягти кінцевої цілі формування оргструктури. Встановлення повних шляхів мережевого графу уможливлює визначення їх тривалості і наявних часових резервів (табл. 3). 
Таблиця 3

Повні шляхи і їх часові параметри

\begin{tabular}{|l|l|c|}
\hline \multicolumn{1}{|c|}{ Повний шлях, $\boldsymbol{L}$} & \multicolumn{1}{|c|}{ Тривалість, $\boldsymbol{t}(\boldsymbol{L})$} & Резерв, $\boldsymbol{R}(\boldsymbol{L})$ \\
\hline $\begin{array}{l}1-2-4-5-6-7-8-9 \\
-10-11-12-13-14- \\
15-16\end{array}$ & $\begin{array}{l}16+8+8+40+8+8+8+80+ \\
400+8+8+8+80+400+8=\end{array}$ & $1088-1088=0$ \\
\hline $\begin{array}{l}1-2-4-5-6-9-10- \\
11-12-13-14-15-16\end{array}$ & $\begin{array}{l}16+8+8+40+8+88+400+8 \\
+8+8+80+400+8=1080\end{array}$ & $1088-1080=8$ \\
\hline $\begin{array}{l}1-2-4-5-6-7-8-9 \\
-10-11-14-15-16\end{array}$ & $\begin{array}{l}16+8+8+40+8+8+8+80+ \\
400+8+88+400+8=1080\end{array}$ & $1088-1080=8$ \\
\hline $\begin{array}{l}1-2-4-5-6-9-10- \\
11-14-15-16\end{array}$ & $\begin{array}{l}16+8+8+40+8+88+400+8 \\
+88+400+8=1072\end{array}$ & $1088-1072=16$ \\
\hline
\end{tabular}

Як видно 3 табл. 3, оптимальним є четвертий варіант повного шляху, оскільки завдяки дугам робіт (6-9 і 11-14) він забезпечує резерв часу тривалістю 16 год. На рис. 4 наведено лінійний графік мережевої моделі матричної оргструктури. Ідентифіковані резерви можна використати шляхом виконання низки робіт під час формування положень про структурні підрозділи середнього і низового рівнів управління.

Застосування методів аналізу і синтезу у поєднанні із теорією множин дозволило виділити елементи структурних компонентів матричних оргструктур, а саме: множину елементів, що репрезентує виконавців певного проекту ( $\left.\left\{\begin{array}{c}c \\ W_{z} \\ z=1\end{array}\right\}\right)$, а також множини елементів лінійного $\left(\left\{\begin{array}{c}a \\ L_{x} \\ x=1\end{array}\right\}\right)$ і функціонального ( $\left.\left\{\begin{array}{c}b \\ F_{y} \\ y=1\end{array}\right\}\right)$ управління виконавцями певного проекту.

На рис. 5 наведено круговий фрактал матричної оргструктури. На представленому рисунку х і у є елементами множини лінійного і, відповідно, функціонального управління виконавцями проектів, які реалізовуються на підприємстві. У свою чергу, z репрезентує виконавців проектів. Верхній лівий індекс кожного елемента z означає номер peaлізовуваного проекту, верхній правий індекс - функціональне підпорядкування керівникам структурних підрозділів підприємства, а нижній індекс - лінійне підпорядкування керівнику відповідного проекту.

Сукупність цих множин є структурною компонентою $\left(\left\{\begin{array}{c}3 \\ s_{k} \\ k=1\end{array}\right\}\right)$ матричної оргструктури за ознакою реалізовуваних проектів. У формалізованому вигляді відношення між цими множинами можна записати так: 


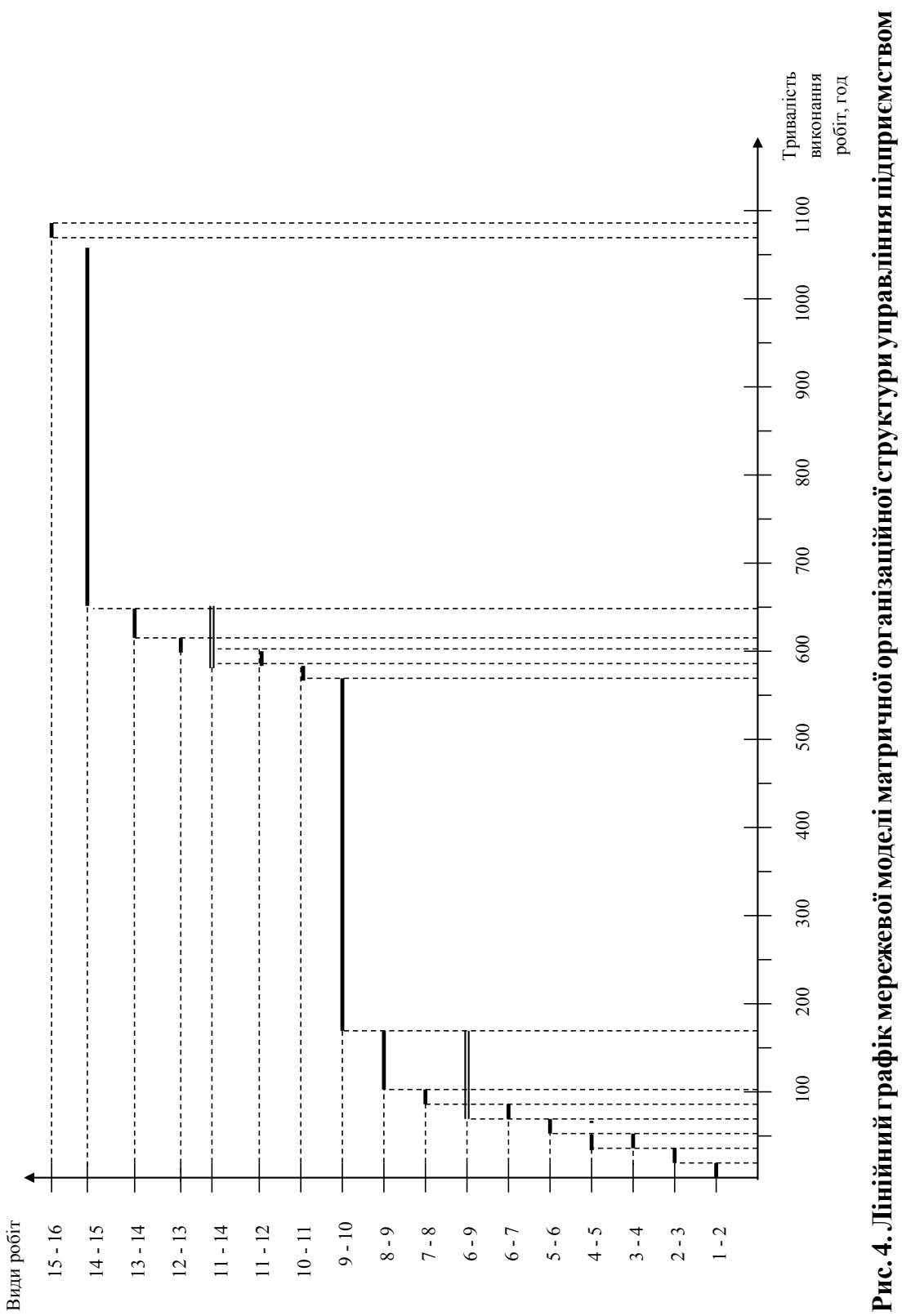




$$
\left\{\begin{array}{c}
c \\
W_{z} \\
z=1
\end{array}\right\} \cup\left\{\begin{array}{c}
a \\
L_{x} \\
x=1
\end{array}\right\} \cup\left\{\begin{array}{c}
b \\
F_{y} \\
y=1
\end{array}\right\} \equiv \cup\left\{\begin{array}{c}
3 \\
s_{k} \\
k=1
\end{array}\right\} .
$$

Множина $\left\{\begin{array}{c}3 \\ s_{k} \\ k=1\end{array}\right\} \in$ не лише об'єднанням множин $\left\{\begin{array}{c}c \\ W \\ z=1\end{array}\right\},\left\{\begin{array}{l}a \\ L_{x} \\ x=1\end{array}\right\} \wedge\left\{\begin{array}{c}b \\ F_{y} \\ y=1\end{array}\right\}$,

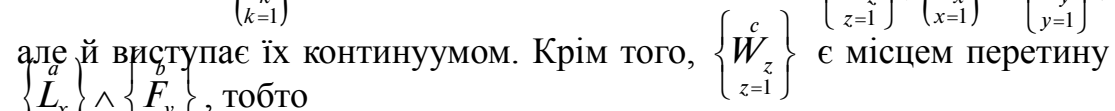
$\left\{\begin{array}{c}L_{x} \\ x=1\end{array}\right\} \wedge\left\{\begin{array}{c}F_{y} \\ y=1\end{array}\right\}$, тобто

$$
\begin{aligned}
& \cup\left\{\begin{array}{c}
3 \\
S_{k} \\
k=1
\end{array}\right\} \supseteq\left(\begin{array}{c}
\left\{\begin{array}{c}
a \\
L_{x} \\
x=1
\end{array}\right\} \cup\left\{\begin{array}{c}
c \\
W_{z} \\
z=1
\end{array}\right\} \\
\left\{\begin{array}{c}
b \\
F_{y} \\
y=1
\end{array}\right\} \cup\left\{\begin{array}{c}
c \\
W_{z} \\
z=1
\end{array}\right\}
\end{array}\right) ; \\
& \left\{\begin{array}{c}
a \\
L_{x} \\
x=1
\end{array}\right\} \cap\left\{\begin{array}{c}
b \\
F_{y} \\
y=1
\end{array}\right\} \equiv\left\{z \mid z \in\left\{\begin{array}{c}
a \\
L_{x} \\
x=1
\end{array}\right\} \wedge z \in\left\{\begin{array}{c}
b \\
F_{y} \\
y=1
\end{array}\right\}\right\} .
\end{aligned}
$$

Загалом кожна структурна компонента матричної оргструктури $\epsilon$ фракталом, тобто самоподібною структурою, малі частини якої в довільному збільшенні $є$ подібними до неї самої.

На рис. 5 жирним кругом позначено $\left\{\begin{array}{c}b \\ F_{y} \\ y=1\end{array}\right\}$, кругом із пунктирною лінією $-\left\{\begin{array}{c}a \\ L_{x} \\ x=1\end{array}\right\}$, кругом із тонкою лінією $-\left\{\begin{array}{c}c \\ W_{z} \\ z=1\end{array}\right\}$.

Враховуючи те, що матрична оргструктура може будуватись не лише за видами реалізовуваних проектів, але й передбачати географічне чи продуктове диференціювання, то вона є сукупністю фракталів $O_{m}=f\left(F_{1}, F_{2} \ldots \ldots . . F_{n}\right)$, де $O_{m}$ - матрична оргструктури; $F_{1}, F_{2} \ldots \ldots . . F_{n}-$ фрактали, які утворюють $O_{m}$.

$$
\text { Таким чином, } O_{m}=f\left(F_{1}, F_{2} \ldots \ldots . . F_{n}\right) \sim \cup\left\{\begin{array}{c}
3 \\
S_{k} \\
k=1
\end{array}\right\} \cup \ldots . \cup \cup\left\{\begin{array}{c}
3 \\
s_{k} \\
k=1
\end{array}\right\}_{n} .
$$

Використання фрактальності в якості властивості матричних оргструктур для збільшення їх масштабу сприяє зростанню резервів часу на формування оргструктури. У випадку, коли це явище супроводжується також приростом показників економічної ефективності, то виникає синергічний ефект, тобто, коли $\Delta M_{o} \Rightarrow \Delta R \Rightarrow \Delta E_{e}$, і $\Delta M_{0}<\Delta E_{e}$ де $\Delta M_{0}$ - відносний додатний приріст структурних компонентів матричної оргструктури $\Delta R$ - відносний додатний приріст резервів часу на формування нових структурних компонентів матричної оргструктури; 
Vilgutska Roksolana, Kazymyra Iryna

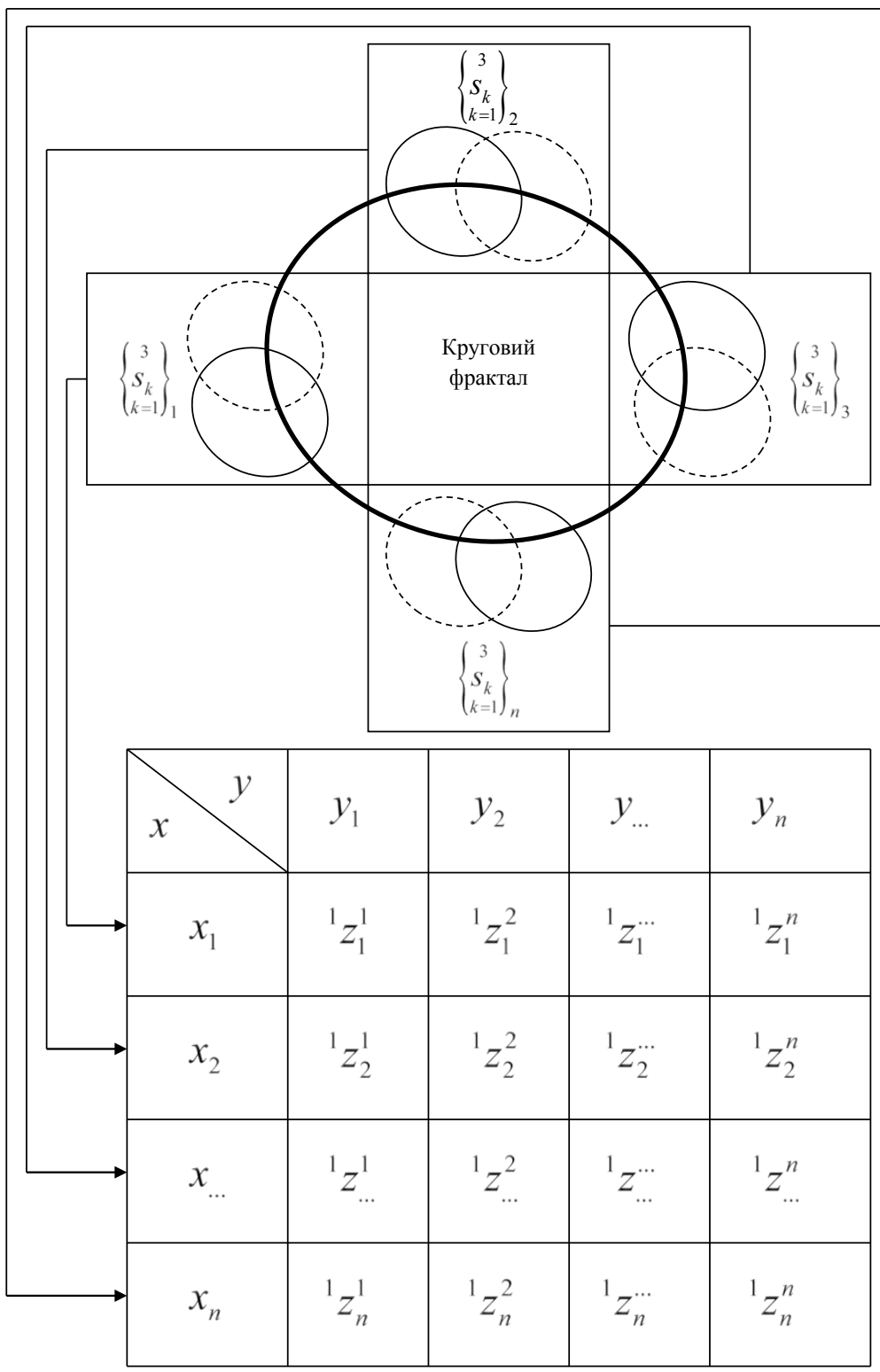

Рис. 5. Круговий фрактал матричної оргструктури 


\section{Chapter «Economic sciences»}

$\Delta E_{e}-$ відносний додатний приріст показників економічного розвитку підприємства.

\section{3. Обгрунтування необхідності реорганізації оргструктури}

Під впливом змін, які відбуваються у внутрішньому і зовнішньому середовищах підприємств, їх оргструктури є динамічними утвореннями, які періодично вимагають реорганізації.

На необхідність реорганізації, здебільшого, вказують такі типові ознаки:

1) неспроможність оргструктури забезпечити необхідну субординацію між посадовими особами і структурними підрозділами;

2) нездатність структурних підрозділів виконувати покладені на них функції, що унеможливлює реалізацію поставлених перед ними цілей.

Спільною основою вищенаведених ознак $\epsilon$ те, що за допомогою оргструктури не вдається повністю або частково виконати цілі, поставлені перед нею загалом і її структурними підрозділами, зокрема. Якщо позначити першу з виділених ознак як $\left\{\begin{array}{c}1 \\ S_{s} \\ s=1\end{array}\right\}$, що є множиною елементів s, які репрезентують мету формування оргструктури, а другу як $\left\{\begin{array}{c}F_{p} \\ p=1\end{array}\right\}$, де сукупність р є множиною елементів у кількості n, то

$$
\begin{aligned}
& f .\left\{\begin{array}{c}
n \\
F_{p} \\
p=1
\end{array}\right\} \mapsto\left\{\begin{array}{l}
m \\
C_{c} \\
c=1
\end{array}\right\} \therefore \\
& \left\{\begin{array}{c}
n \\
F_{p} \\
p=1
\end{array}\right\} \sim\left\{\begin{array}{l}
m \\
C_{c} \\
c=1
\end{array}\right\} \because p \sim c ;\left\{\begin{array}{l}
1 \\
S_{s} \\
s=1
\end{array}\right\} \subset\left\{\begin{array}{c}
m \\
C_{c} \\
c=1
\end{array}\right\} ; \\
& \left\{\begin{array}{l}
m \\
C_{c} \\
c=1
\end{array}\right\} \cap\left\{\begin{array}{c}
1 \\
S_{s} \\
s=1
\end{array}\right\} \because \text { якщо } c \subset\left\{\begin{array}{l}
1 \\
S_{s} \\
s=1
\end{array}\right\} \wedge c \subset\left\{\begin{array}{c}
m \\
C_{c} \\
c=1
\end{array}\right\}, \\
& \text { то } c \subset\left\{\begin{array}{l}
m \\
C_{c} \\
c=1
\end{array}\right\} \cap\left\{\begin{array}{l}
1 \\
S_{s} \\
s=1
\end{array}\right\} .
\end{aligned}
$$

У даному випадку,оскільки $p \sim c, \epsilon$ підстави стверджувати, що $\left\{\begin{array}{c}\stackrel{n}{F_{p}} \\ p=1\end{array}\right\} \cong\left\{\begin{array}{c}1 \\ S_{s} \\ s=1\end{array}\right\}$.

Конгруентність дозволяє в якості критерію для аргументації доцільності реорганізації оргструктури розглядати рівень реалізації встановлених перед нею цілей. Застосовуючи метод декомпозиції цілей 
у сукупності із положеннями теорії кілець, здійснено градацію цілей оргструктури і параметризовано їх. Базуючись на теорії кілець, встановлено, що кількість цілей на кожному ієрархічному рівні є сукупністю дійсних чисел, які утворюють алгебраїчне кільце

$$
f(x)=\left(\begin{array}{ll}
x & 0 \\
0 & x
\end{array}\right),
$$

де $f$ - гомоморфізм кілець; $x$ - дійсне число.

Враховуючи цю особливість, виділено етапи обробки даних для аргументування необхідності реалізації змін у чинній оргструктурі (рис. 6) ${ }^{1}$.

У табл. 4 наведено матрицю трактування значень коефіцієнтів, які характеризують оргструктуру за критерієм реалізації встановлених цілей.

Якщо $K_{1} \succ 1$, то це означає, що $Z_{p_{1}} \succ Z_{k_{1}} \wedge x_{2} \rightarrow x_{1}$. Така сама логіка лежить в основі трактування $K_{2} \succ 1$, тобто $Z_{p_{2}} \succ Z_{k_{2}} \wedge x_{3} \rightarrow x_{2}$. У свою чергу, набуття коефіцієнтом $K_{1}$ значення, меншого за 1 , означає, що $Z_{p_{1}} \prec Z_{k_{1}} \wedge x_{1} \equiv x_{2}$. Якщо $K_{2} \prec 1$, то $Z_{p_{2}} \prec Z_{k_{2}} \wedge x_{2} \equiv x_{3}$. Беручи до уваги вищенаведені пояснення, значення коефіцієнтів $K_{3}$ i $K_{4}$ можна використовувати для аргументації необхідності реорганізації оргструктури. Якщо $K_{3} \wedge K_{4} \leq 1$, то необхідності реорганізувати оргструктуру немає. У всіх інших випадках необхідність реорганізації

${ }^{1}$ Примітки до рис. 6: $x_{1}$ - кількість цілей, які має реалізувати підприємство; $x_{2}-$ кількість цілей, поставлених перед підрозділами підприємства; $\mathrm{x}_{3}$ - кількість цілей, поставлених перед працівниками; $x_{4}$ - кількість реалізованих підприємством цілей; $x_{5}$ - кількість цілей, реалізованих підрозділами підприємства; $x_{6}$ кількість цілей, реалізованих працівниками; $K_{1}$ - коефіцієнт структурованості встановлених цілей за підрозділами підприємства, частки одиниці; $K_{2}-$ коефіцієнт структурованості встановлених цілей за працівниками підрозділів підприємства; $K_{3}$ - коефіцієнт структурованості реалізованих цілей за підрозділами підприємства, частки одиниці; $K_{4}$ - коефіцієнт структурованості реалізованих цілей за працівниками підрозділів підприємства, частки одиниці; $Z_{p_{1}}$ - просте значення кількості цілей, які має реалізувати підприємство з урахуванням цілей, що стоять перед його підрозділами; $Z_{p_{2}}$ - просте значення кількості цілей, які мають реалізувати підрозділи підприємства; $Z_{p_{3}}$ - просте значення кількості цілей, які мають реалізувати працівники підприємства; $Z_{p_{4}}$ - просте значення кількості цілей, реалізованих підприємством із урахуванням цілей, що стоять перед його підрозділами; $Z_{k_{1}}$ - кумулятивне значення кількості цілей, які має реалізувати підприємство з урахуванням цілей, що стоять перед його підрозділами; $Z_{k_{2}}-$ кумулятивне значення кількості цілей, які мають реалізувати підрозділи підприємства; $Z_{k_{3}}$ кумулятивне значення кількості цілей, які мають реалізувати працівники підприємства; $Z_{k_{4}}$ - кумулятивне значення кількості цілей, реалізованих підприємством із урахуванням цілей, що стоять перед його підрозділами. 


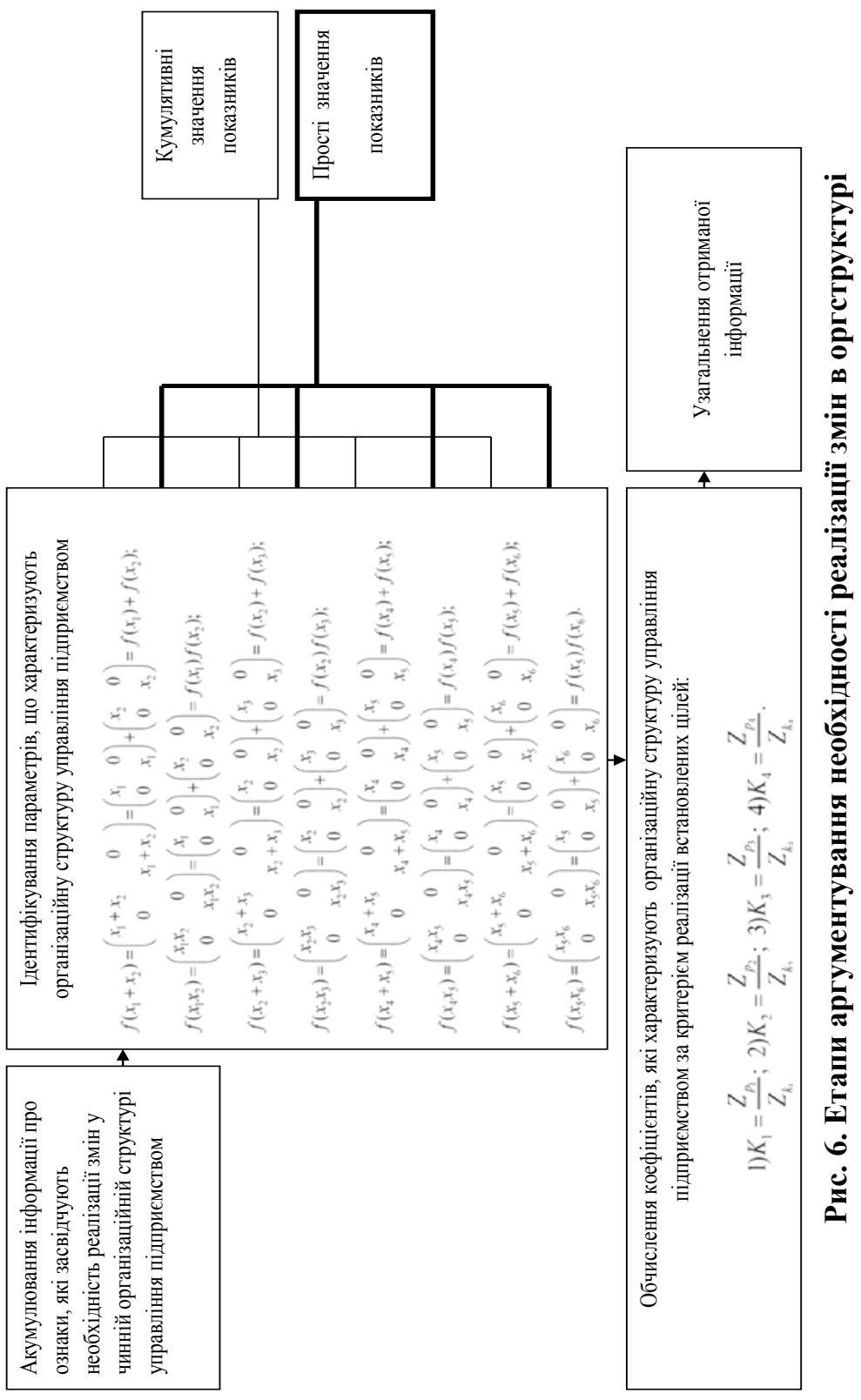


Матриця трактування значень коефіціснтів за критерієм реалізації встановлених цілей

\begin{tabular}{|c|c|c|c|}
\hline \multirow{2}{*}{ Коефіціснти } & \multicolumn{3}{|c|}{ Можливі варіанти значень обчислених коефіціснтів } \\
\cline { 2 - 4 } & $\succ 1$ & $\prec 1$ & $=1$ \\
\hline$K_{1}$ & $K_{1} \succ 1$ & $K_{1} \prec 1$ & $K_{1} \uparrow 1$ \\
\hline$K_{3}$ & $K_{3} \succ 1$ & $K_{3} \prec 1$ & $K_{3}=1$ \\
\hline$K_{2}$ & $K_{2} \succ 1$ & $K_{2} \prec 1$ & $K_{2} \uparrow 1$ \\
\hline$K_{4}$ & $K_{4} \succ 1$ & $K_{4} \prec 1$ & $K_{4}=1$ \\
\hline
\end{tabular}

викликана тим, що на певних ієрархічних рівнях управління не реалізовуються встановлені цілі.

На практиці організаційні зміни, які передбачають реорганізацію оргструктури, відбуваються переважно тоді, коли упродовж тривалого періоду часу (мінімум рік) спостерігаються типові проблеми використання наявної оргструктури, які дозволяють 3 достатньо високим рівнем вірогідності встановити причини їх виникнення. Побудова рядів динаміки зміни значень коефіцієнтів, які характеризують оргструктуру за критерієм реалізації встановлених цілей упродовж року, ідентифікування приростів цих показників, а також встановлення стійкості їх виникнення є важливим етапом аргументації необхідності реорганізації чинної оргструктури (табл. 5).

Таблиця 5

Матриця зміни значень коефіцієнтів за кварталами

\begin{tabular}{|c|c|c|c|c|}
\hline \multirow{2}{*}{ Коефіціснти } & \multicolumn{4}{|c|}{ Порядкові номери кварталів } \\
\cline { 2 - 5 } & $\mathbf{1}$ & $\mathbf{2}$ & $\mathbf{3}$ & $\mathbf{4}$ \\
\hline$K_{1}$ & $K_{1}^{1}$ & $K_{1}^{2}$ & $K_{1}^{3}$ & $K_{1}^{4}$ \\
\hline$K_{2}$ & $K_{2}^{1}$ & $K_{2}^{2}$ & $K_{2}^{3}$ & $K_{2}^{4}$ \\
\hline$K_{3}$ & $K_{3}^{1}$ & $K_{3}^{2}$ & $K_{3}^{3}$ & $K_{3}^{4}$ \\
\hline$K_{4}$ & $K_{4}^{1}$ & $K_{4}^{2}$ & $K_{4}^{3}$ & $K_{4}^{4}$ \\
\hline
\end{tabular}

Примітка: умовні позначення: верхній індекс коефіцієнтів вказує на їх значення у відповідному кварталі 


\section{Chapter «Economic sciences»}

Ця матриця, у залежності від того, наскільки швидко аналітики підприємства здатні акумулювати і обробляти управлінську інформацію, може будуватись не лише за кварталами, але й за півріччями, місяцями або декадами. Матриця зміни значень коефіцієнтів необхідна для встановлення характеру відхилень, які мали місце упродовж аналізованого періоду. Ці відхилення можна обчислювати за допомогою базових і ланцюгових показників приросту:

1) обчислення базових приростів значень коефіцієнтів, які характеризують оргструктуру:

$$
\begin{aligned}
& \Delta_{1}=K_{1}^{2}-K_{1}^{1} ; \Delta_{4}=K_{2}^{2}-K_{2}^{1} ; \Delta_{7}=K_{3}^{2}-K_{3}^{1} ; \Delta_{10}=K_{4}^{2}-K_{4}^{1} ; \\
& \Delta_{2}=K_{1}^{3}-K_{1}^{1} ; \Delta_{5}=K_{2}^{3}-K_{2}^{1} ; \Delta_{8}=K_{3}^{3}-K_{3}^{1} ; \Delta_{11}=K_{4}^{3}-K_{4}^{1} ; \\
& \Delta_{3}=K_{1}^{4}-K_{1}^{1} ; \Delta_{6}=K_{2}^{4}-K_{2}^{1} ; \Delta_{9}=K_{3}^{4}-K_{3}^{1} ; \Delta_{12}=K_{4}^{4}-K_{4}^{1} .
\end{aligned}
$$

2) обчислення ланцюгових приростів значень коефіціснтів, які характеризують оргструктуру:

$$
\begin{aligned}
& \Delta_{13}=K_{1}^{2}-K_{1}^{1} ; \Delta_{16}=K_{2}^{2}-K_{2}^{1} ; \Delta_{19}=K_{3}^{2}-K_{3}^{1} ; \Delta_{22}=K_{4}^{2}-K_{4}^{1} ; \\
& \Delta_{14}=K_{1}^{3}-K_{1}^{2} ; \Delta_{17}=K_{2}^{3}-K_{2}^{2} ; \Delta_{20}=K_{3}^{3}-K_{3}^{2} ; \Delta_{23}=K_{4}^{3}-K_{4}^{2} ; \\
& \Delta_{15}=K_{1}^{4}-K_{1}^{3} ; \Delta_{18}=K_{2}^{4}-K_{2}^{3} ; \Delta_{21}=K_{3}^{4}-K_{3}^{3} ; \Delta_{24}=K_{4}^{4}-K_{4}^{3} .
\end{aligned}
$$

Аналізування базових і ланцюгових приростів зміни значень коефіцієнтів, які характеризують оргструктуру за критерієм реалізації встановлених цілей, завершується узагальненням отриманих результатів і формуванням висновку про необхідність реорганізації чинної оргструктури. Свідченням необхідності реорганізації $\epsilon$ встановлення явища $K_{3} \wedge K_{4} \leq 1$ і стійкої тенденції виникнення нульових або від'ємних приростів цих коефіцієнтів. На рис. 7 наведено послідовність етапів аргументації необхідності реорганізування чинної оргструктури. Етапи, виділені на рис. 7, засвідчують наявність управлінської проблеми, яка вимагає розв'язання, тобто прийняття певного управлінського рішення. Після того, як проблема встановлена і зібрана відносно повна інформація про іiі сутність і обставини виникнення, відбувається формування альтернативних варіантів розв'язання проблеми.

На основі встановлення певних пріоритетних для керівників підприємств критеріїв ці альтернативи аналізуються і обирається той варіант рішення, який задовольняє обрані критерії. У результаті реалізації обраних рішень відбувається реорганізування оргструктури. 
3 позиції теорії множин реорганізація оргструктури, яка спричиняє зміну кількості її компонентів, зумовлює зміну потужності множини. Потужність оргструктури до реорганізації можна записати так:

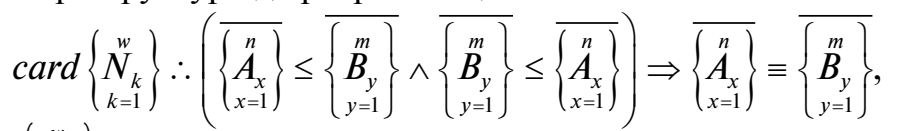

де $\operatorname{card}\left\{\begin{array}{c}N_{k}^{w} \\ k=1\end{array}\right\}$ - потужність оргструктури;

$\overline{\left\{\begin{array}{l}n \\ A_{x} \\ x=1\end{array}\right\}}$ - потужнісість множини елементів х, що утворюють структур-

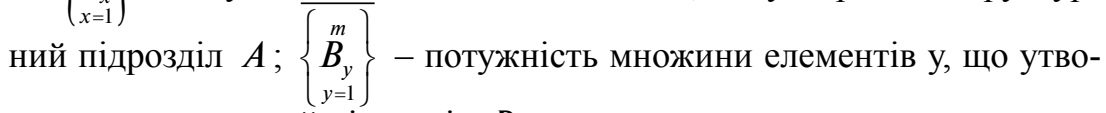
рюють структурний підрозділ $B$.

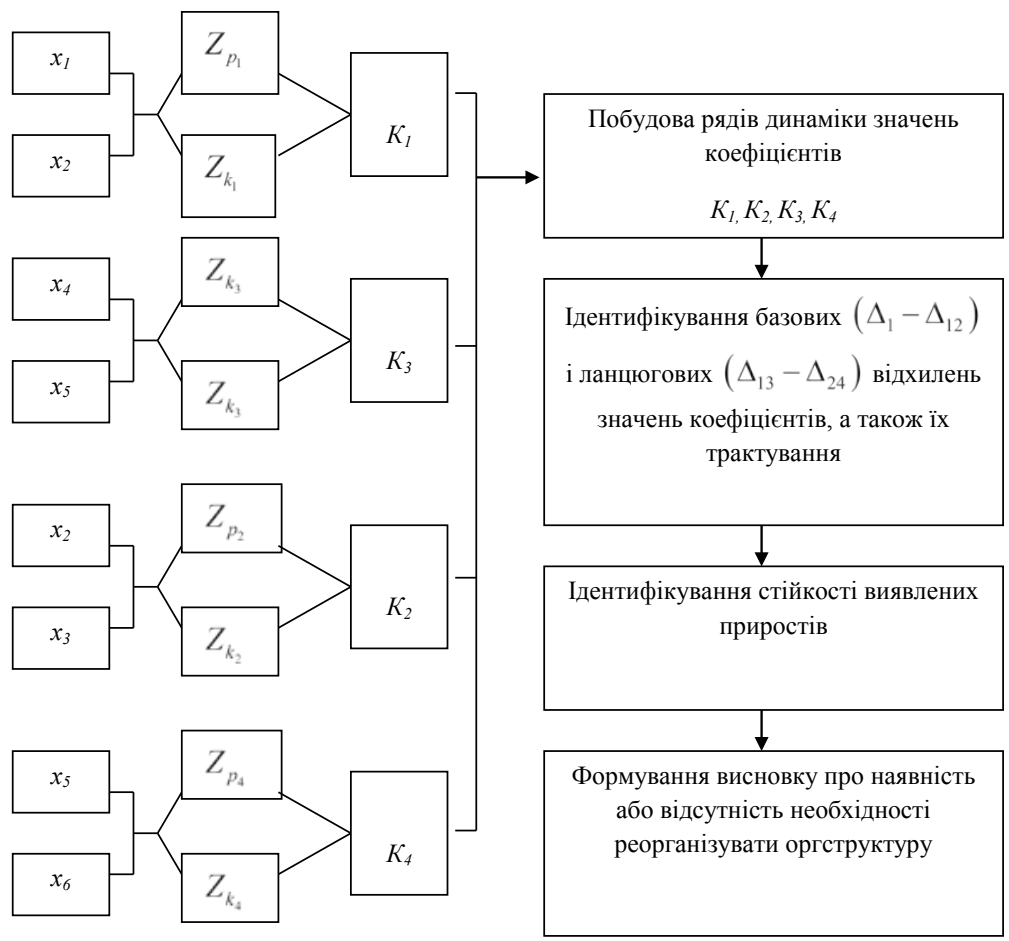

Рис. 7. Послідовність етапів аргументації необхідності реорганізування оргструктури 
Після реорганізації card $\left\{\begin{array}{c}w \\ N_{k} \\ k=1\end{array}\right\}$ може збільшуватись або зменшуватись у залежності від того, як саме відбувається реорганізація. На рис. 8 наведено умовну траєкторію діаграми зміни потужності оргструктури упродовж п’яти років.

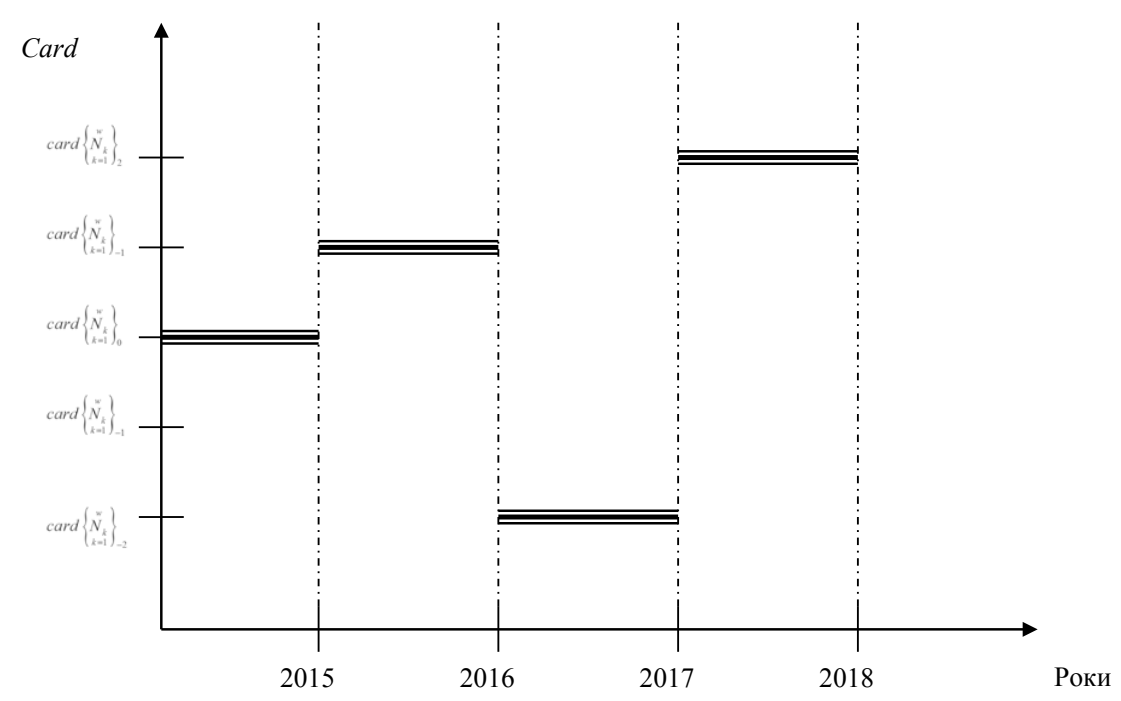

Рис. 8. Траєкторія діаграми зміни потужності оргструктури

Примітки: нижні додатні індекси множин вказують на зростання потужності базової множини. На рис. 8 базову множину позначено нижнім індексом «0»; нижні від'ємні значення множин вказують на зниження потужності базової множини.

На основі побудови ряду динаміки card $\left\{\begin{array}{l}w \\ N \\ k=1\end{array}\right\}$ можливим є обчислити показник мобільності оргструктури. Для виконання цього завдання пропонуємо таку формулу:

$$
K_{m}=\sum_{i=1}^{n} Z_{i} ; Z_{i} \equiv \operatorname{card}\left\{\begin{array}{c}
w \\
N_{k} \\
k=1
\end{array}\right\}_{i}-\operatorname{card}\left\{\begin{array}{c}
N_{k}^{w} \\
k=1
\end{array}\right\}_{o},
$$

де $K_{m}$ - показник мобільності оргструктури; $\sum_{i=1}^{n} Z_{i}-$ кількість змін в оргструктурі, які змінили іiі потужність упродовж i - го періоду; n - 
кількість часових періодів; card $\left\{\begin{array}{l}N_{k}^{w} \\ k=1\end{array}\right\}_{i}$ - потужність оргструктури упродовж і - го періоду; card $\left\{\begin{array}{l}N_{k}^{w} \\ k=1\end{array}\right\}_{o}-$ потужність оргструктури на момент їі створення внаслідок заснування підприємства.

Цей показник має сенс тоді, коли використовується у комплексі із показниками економічного розвитку підприємства. На основі виявлення кореляційних залежностей між його значенням та іншими показниками економічного розвитку підприємства можливим є побудувати аналітико-рекомпозиційні моделі, які демонструватимуть, наскільки чинна оргструктури відповідає потребам підприємства, як іiї реорганізація позначається на економічному розвитку організації.

\section{4. Висновки}

Аргументування доцільності реорганізації чинної оргструктури базується на критерії реалізації цілей, покладених на оргструктури загалом і окремих іiї підрозділів, зокрема. Доведено, що система цілей оргструктури характеризується конгруентністю. Враховуючи цю властивість, керівники підприємства отримують можливість забезпечувати зростання значень показників економічного розвитку підприємства за рахунок реалізації організаційних змін, спрямованих на підвищення рівня мобільності чинної оргструктури. Запропонований матричномережевий підхід передбачає побудову фракталу оргструктури. У результаті застосування цього підходу в поєднанні з інструментарієм теорії мережевих графів можливим є ідентифікування синергічного ефекту, зокрема у формі появи економії витрат часу і коштів на просторовий розвиток чинної оргструктури.

\section{Список літератури:}

1. Антонов В.М. Інтелектуально-математичний менеджмент. Кіберакмеологічна концепція: Монографія / Антонов В.М. - К.: КНТ, 2007. $528 \mathrm{c}$.

2. Вільгуцька Р.Б. Моделювання організаційних структур управління підприємств / Р.Б. Вільгуцька // Науковий журнал «Бізнес Інформ». - 2014. №. 5. - C. 145-150.

3. Георгіаді Н.Г. Сутність і види організаційних структур управління підприємствами / Н.Г. Георгіаді, Р.Б. Вільгуцька // Сталий розвиток економіки. Всеукраїнський науково-виробничий журнал. - 2012. - № 7(17). - С. 94-98.

4. Кігель В.Р. Методи і моделі підтримки прийняття рішень у ринковій економіці / В.Р. Гігель: Монографія. - К.: ЦУЛ, 2003. - 202 с. 


\section{Chapter «Economic sciences»}

5. Мазаракі А.А. Менеджмент: теорія і практика: Навчальний посібник / А.А. Мазаракі, Г.С. Мошек. - К.: КНТЕУ, 2007. - 584 с.

6. Heorhiadi N. Method of morphological analysis of enterprise management organizational structure / N. Heorhiadi, N. Iwaszczuk, R. Vilhutska // Econtechmod. An international quarterly journal. Lublin-Rzeszow-2013.-Vol. 2. No. 4.-P. 17-27.

\section{References:}

1. Antonov, V.M. (2007). Intelektualno-matematychnyy menedzhment. Kiberatmeolohichna konceptsiya: Monohrafiya [Intellectual-mathematical management. Cyberchemological concept: Monograph]. KNT, Kyiv, Ukraine.

2. Vilhutska, R.B. (2014). Modeling organizational structures of enterprise management. Naukovyy zhurnal «Biznes Inform», vol. 5, pp. 145-150.

3. Heorhiadi, N.H. and Vilhutska. R.B., (2012). The essence and types of organizational structures of management of enterprises. Stalyy rozvytok ekonomiky. Vseukrayinskyy naukovo-vyrobnychyy zhurnal, vol. 7(17), pp. 94-98.

4. Kihel, V.R. (2003). Metody i modeli pidtrymky pryynyattya rishen u rynkoviy ekonomitsi: Monohrafiya [Methods and models of decision support in a market economy: Monograph]. TSUL, Kyiv, Ukraine.

5. Mazaraki, A.A. and Moshek, H.Ye. (2007). Menedzhment: teoriya i praktyka [Management: Theory and Practice]. KNTEU, Kyiv, Ukraine.

6. Heorhiadi, N. Iwaszczuk, N. and Vilhutska, R. (2013). "Method of morphological analysis of enterprise management organizational structure". Econtechmod. An international quarterly journal. Lublin-Rzeszow, vol. 2, No. 4, pp. 17-27. 